\begin{tabular}{|c|c|}
\hline \multirow{3}{*}{ 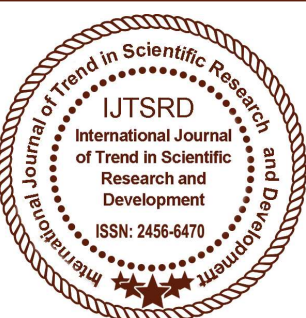 } & $\begin{array}{l}\text { International Journal of Trend in Scientific } \\
\text { Research and Development (IJTSRD) }\end{array}$ \\
\hline & International Open Access Journal \\
\hline & ISSN No: 2456 - 6470 | www.ijtsrd.com | Volume - 2 | Issue - 5 \\
\hline
\end{tabular}

\title{
Effects of Organic Carbon Content and Water Stable Aggregate on The Development of Rill and Gully Erosion in Aramoko-Ekiti
}

\author{
Michael O. Dada ${ }^{1}$, Joseph O. Adam ${ }^{2}$ \\ ${ }^{1}$ Senior Lecturer, ${ }^{2}$ Chief Lecturer, Department of Civil Engineering \\ Federal Polytechnic, P.M.B., Ado - Ekiti, Nigeria, West Africa
}

\begin{abstract}
Field geological study of the area revealed that the erosion hazard has remained active over the years, defying control measures put in place by government, communities and individuals. Assessments of effects of organic carbon content and water stable aggregates on the development of rill and gully erosion in Iloro, Ikoyi, Alele and Atiba of Aramoko-Ekiti, Ekiti-State, Nigeria is presented in this study. Soil samples were collected from different depths of gully sites and their geotechnical properties analyzed using organic carbon content and triaxial tests. Results revealed that the soil in the study area has low organic carbon ranges from 1.39 to $1.43 \%$, which results in less organic carbon, thus high erosion. The triaxial test results ranges from 6 to 150 . These could be deduced that the soil is vulnerable to agents of gully erosion such as rainfall, slope of land-surface and human activities. An integrated approach including watershed management strategies, construction of ditches, retention pits at appropriate locations and a long-term re-vegetation strategy is suggested for controlling soil erosion and gulling in the study area.
\end{abstract}

Keywords: Landform; Organic carbon content; Water stable aggregate; Rill erosion; Gully erosion

\section{INTRODUCTION}

Soil erosion is a dynamic geomorphic event operating on the landscape. It is defined as the process leading to the general degradation of ground surface. It is a situation in which soil is removed at a rate faster than that at which new soil is formed. Water and wind erosion are two types of soil erosion commonly found in Nigeria. Water erosion is prevalent in southern Nigeria. This is due to disperse action of rain and the transportation power of storm water runoff [5]. When a plot of land is first cleared of forest, little erosion will occur until the action of rain splash has broken down the soil aggregates and sealed the layer openings. At first, the soil is removed rather in uniform thin layers, a process termed as Sheet erosion. Following this change over, land flow begins to pick up and carry soil particles - the process is called Entrainment [6].

This geometric event may degenerate into sheet, rill or gully erosion. Rills are parallel grooves of little depth covering the land surface, which can easily be filled through normal cultivation. Formation of rills is one of the consequences of flowing water. The topography of the study area is mountainous and the hills were claimed to be of advantages to the people of the town during the days of the inter-tribal's wars. The effect of this unique topography is that it has produced a sort of sturdy and determined people capable of fighting against the forces of nature for their existence. The hills that gave security advantage to the early settlers are now cause(s) of serious erosion problems to the people of the town. The development and destruction of the vegetable for the purpose of expansion has now created many gullies in the town [1].

The aim of this paper is to assess the effects of soil organic carbon content and water stable aggregate on the development of rill and gully erosion in the study area. The objectives of the research are to determine the engineering properties of the soil and evaluate the effects and causes of erosion problems. The scope of this research would be limited to investigating the effects of organic carbon content and water stable aggregates on the development of rills and gully erosion in Aramoko-Ekiti. 
The study area is Aramoko-Ekiti as shown in Fig.1, the head quarter of Ekiti West Local Government in Ekiti state. Ekiti is one of the states that experience very high rainfall intensity in Nigeria. However, such towns as Aramoko whose soils are sensitive and susceptible to collapsing because of their loose nature. The problem of erosion is very serious and needs immediate attention. Soil erosion is one of the most serious problems facing civil engineering projects today. Unfortunately, many people do not feel that erosion of the soil resource by wind and water is a pressing problem. There is need for its investigation to enable the Civil Engineers to use the soil economically, to predict their Engineering properties and performance under field condition to know the causes of the development of rill and gully erosion in the area.

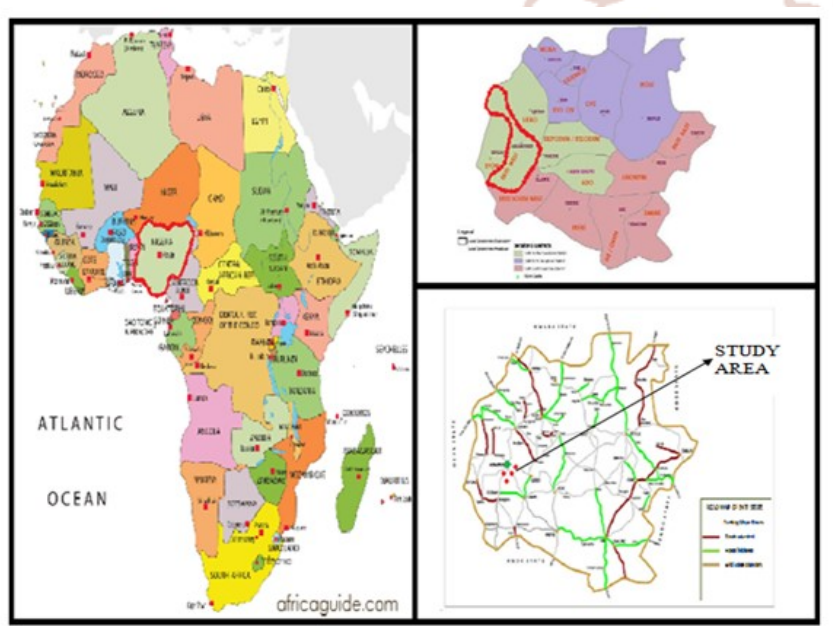

Figure 1: The map showing the location of the study area

\section{A. Occurrence of Soil Erosion}

Usually, it occurs at a low level but can become a problem when the ecological balance is disturbed by human's activities or severe weather. The risk of erosion by water is higher when soils with a high sand or silt content is exposed to heavy rainfall. It is crucial to consider rainfall and runoff factors when assessing a water erosion problem. Although the soil erosion caused by long lasting or less-intense rainfall is not spectacular. Nevertheless, soil movement by rainfall is most noticeable during the short time, highintensity thunderstorms and the amount of soil loss can be considerable especially when compounded over time. While the excess water on a slope that cannot be absorbed into the soil or trapped on the surface, the runoff will occur. The amount of runoff can be increased if infiltration is reduced due to soil compaction [6].
Besides, the unit soil volume loss is usually affected by shear strength, compressive strength and rainfall intensities but less influenced by bed slope [6].

\section{B. Soil Erodibility}

Soil Erodibility is an estimate of the ability of soils to resist erosion in term of the physical characteristics of soil. Compacted subsurface soil layers result in decreased infiltration and increased runoff. A formation of a soil crust, can create the decrease of infiltration, however, normally the growth of runoff water is attended by the greater soil erosion problems. There is a definite link between erosion and soils. The original soils tend to be less erodible than the exposed subsurface soils on eroded sites due to their lower organic matter or poorer structure. The lower nutrient levels usually related with subsoil contribute to lower crop yields and generally poorer crop cover, which in turn provides less crop protection for the soil [6].

\section{Gully Erosion}

This is one of the most significant sources of sediment to streams. Gullies start when concentrated, fast flowing water into a small surface depression caused naturally on the land surface. The energy of water scours away the soil and undermines the vegetation. Once the vegetation and top soil are removed, gullies spread rapidly up and down the drainage lines until there is insufficient run off to continue the erosion that forms the gullies and gradually becomes stable. Once formed, gullies could continue to generate sediment long after the triggering causes have ceased [2].

\section{Rill Erosion}

Rill Erosion is a process in which numerous small channels, typically a few inches deep are formed. It occurs mainly on recently cultivated soils or on cuts and fills. It is the concentration of surface water into deeper, faster flowing channels, which flow in depression or low points through paddocks. It is often described as the intermediate stage between sheet and gully erosion. Rill erosion is common in agricultural land devoid of vegetation and soils often seen in cropping areas after tillage [2].

\section{E. Effects of Soil Erosion}

The Soil Erosion always have effects on soil properties, vegetation, topography and climate. The negative changes caused by erosion such as wind, rain bank erosion include farmland productivity losses, damage to building structures such as bridges, roads. [2] defined the on-site and off-site effects. On-site 
effects means extension of the elimination of the impact of soil erosion of valuable topsoil. Crop emergence, growth and yield are direct impacts of the loss of natural and applied fertilizer and soil nutrients. Seeds and plants may interfere with or completely abolish the erosion site. Organic matter in soil residues and any applicable fertilizer are relatively lightweight and can be transported off-site especially in the spring thaw conditions.

While the off-site effect is not always obvious as onsite effects, but eroded soil, deposited down slope can inhibit or delay the emergence of the seed, bury small seedling, need to replant in the affected areas. Soil quality, structure, stability and texture can be affected by the loss of soil. The breakdown of aggregates and the removal of smaller particles or entire layers of soil or organic matter can weaken the structure and even change the texture. Textural changes can in turn affect the water-holding capacity of the soil, making it more susceptible to extreme condition such as drought. According to [6], sediment can contribute to road damage, accelerate bank erosion and reduce downstream water quality. They can frequently transport with eroded soil pollution or contamination of water downstream and entertainment district. Other effects of erosion include change of soil texture, loss of nutrient, loss of soil, silting up of reservoirs, frequent floods, damage of engineering structures, and pollution by the sediment, degradation of arable land and transport of polluting chemicals absorbed by the eroded soil particles.

Soil erosion removes more liable materials from soil with low percentage of soil organic carbon because soil organic content glues aggregates together and stabilizes soil structure making the soil resistant to erosion thereby affecting aggregates stability [6].

\section{F. Organic Carbon Content}

The amount of organic carbon in soil depends on soil texture, climate, vegetation and historical and current land use management. Soil texture affects organic carbon content because the stabilizing properties that clay has on organic matter can be trapped into the very small spaces between clay particles making them inaccessible to microorganisms and thereby slowing decomposition [3]. In addition, clay offers chemical protection to organic matter through adsorption onto clay surfaces, which again prevents organic matter from being decomposed by bacteria. Soil with high clay content therefore tends to have higher organic carbon content than soils with low clay content under similar land use and climate conditions [4].

\section{G. Water Stable Aggregates}

Soil aggregates are groups of soil particles that bind to one another more strongly than to adjacent particles. Aggregates stability refers to the ability of soil aggregate to resist disintegration when disruptive forces associated with tillage and water or wind erosion are applied. Water stability of aggregates in many soils is shown to depend on organic materials. The organic binding agents have been classified into transient mainly polysaccharides, temporary roots and fungi hyphae persistent resistant aromatic components associated with polyvalent metal cation and strongly solved polymers. The water stability micro-aggregates depend on the persistence of organic binding agents and appear to be a characteristic of the soil [3].

\section{H. Triaxial Test}

This test subjects the soil specimen to three compressive stresses at right angles to each other. These stresses being increased until the sample fails in shear. To deduce the shear strength parameter; friction angle, cohesion and angle of internal friction were considered.

\section{MATERIALS AND METHODS}

Soil samples were taken along the rills and gullies in the study area from four (4) locations namely Iloro, Ikoyi, Alele and Atiba to the laboratory for tests. The coordinates of the sampling points were taken using Geographical Positioning System (GPS). The details of the soil samples were shown in Table 1.

TABLE 1: Details of the soil samples

\begin{tabular}{|c|c|c|}
\hline LOCATION & EASTINGS & NORTHINGS \\
\hline ATIBA & $7^{0} 42^{\prime} 23.653^{\prime \prime}$ & $5^{0} 2^{\prime} 39.317^{\prime \prime}$ \\
\hline ALELE & $7^{0} 42^{\prime} 23.264 ”$ & $5^{0} 2^{\prime} 38.214 ”$ \\
\hline IKOYI & $7^{0} 42^{\prime} 23.433 ”$ & $5^{0} 2^{\prime} 37.31 ”$ \\
\hline ILORO & $7^{0} 42^{\prime} 23.22^{\prime \prime}$ & $5^{0} 2^{\prime} 38.219^{\prime}$ \\
\hline
\end{tabular}

Field assessments were conducted using visual inspection and GPS. This comprises of geological and other useful information. Organic Carbon and Triaxial laboratory tests were performed on the samples taken to determine organic content and shear strength parameters of the soil.

\section{Results and Discussion}

Field observation showed that the soil are predominantly sandy with high void ratio and various measures taken to curb the menace of soil erosion in 
the study area were design and construction of drainage channels to prevent soil loss to surface runoff, massive afforestation, proper housing layout, environmental education programs among others.

Table 2: Triaxal Test Result

\begin{tabular}{|c|c|c|}
\hline Location & $\begin{array}{c}\text { Cohesion } \\
\text { (c) } \mathrm{kN} / \mathrm{m}^{2}\end{array}$ & $\begin{array}{c}\text { Angle of Internal } \\
\text { friction (ø) }\end{array}$ \\
\hline Sample A & 71 & $10^{0}$ \\
\hline Sample B & 75 & $8^{0}$ \\
\hline sample C & 89 & $6^{0}$ \\
\hline Sample D & 22 & $15^{0}$ \\
\hline
\end{tabular}

From Table 2, the result shows that the angle of friction ranges between $6^{0}$ and $15^{0}$. These values are low when compared with $26^{\circ}$ angle of friction classified as average and thus can only be of little resistance to the effect of surface runoff.

Table 3. Summary of the Organic Carbon present in the Soil Samples

\begin{tabular}{|c|c|c|c|c|c|c|}
\hline $\begin{array}{c}\text { Sample } \\
\text { location }\end{array}$ & $\begin{array}{c}\text { Titre value } \\
\text { for blank }\end{array}$ & $\begin{array}{c}\text { Titration } \\
(\mathbf{T})\end{array}$ & $\begin{array}{c}\mathbf{A}=\mathbf{B} \\
-\mathbf{T}\end{array}$ & $\begin{array}{c}\text { Molars of acid } \\
\text { used }(\mathbf{m})\end{array}$ & $\begin{array}{c}\mathbf{B}=\mathbf{m} \mathbf{x} \mathbf{0 . 0 0 3} \mathbf{x} \\
1.33 \mathbf{x} \mathbf{1 0 0}\end{array}$ & $\begin{array}{c}\text { \% of organic } \\
\text { carbon } \\
=\mathbf{a} \mathbf{x} \mathbf{~ b}\end{array}$ \\
\hline Atiba & 25.80 & 18.30 & 7.50 & 0.47 & 0.18753 & 1.41 \\
\hline Alele & 25.80 & 18.40 & 7.40 & 0.47 & 0.18753 & 1.39 \\
\hline Ikoyi & 25.80 & 18.20 & 7.60 & 0.47 & 0.18753 & 1.43 \\
\hline Iloro & 25.80 & 18.40 & 7.40 & 0.47 & 0.18753 & 1.39 \\
\hline
\end{tabular}

It is observed that the organic carbon content of the soil from the study area ranges between 1.39 and $1.43 \%$. Thus, the average soil from the study area has low carbon content.

\section{IV.Conclusion and Recommendation}

From the above study, it can be concluded that the organic carbon content present in and shear strength of the soil is below standard specification. This resulted in high erosion and with soil that is predominantly sandy with high void ratio; it is subjected to most severe gulling. The underlying soils with high void ratio and low density create gully erosion because of the high seepage/pressures generated from the high flow velocities. Therefore, erosion is rampant in the study area because organic carbon content and water stable aggregates favoured the development of rill and gully in most parts of the study area.

It is recommended that an adequate control measure like construction of retention pits and ditches may be adopted. Considering the nature of the topography of the study area, the town can be developed through a comprehensive contour planning of the layout of land use. The buildings should be built along terrace rather than in the haphazard pattern they were done in the area. A general awareness programme should be organized to enlighten and sensitize the populace of the nature and action of erosion as well as of the consequence of the activities. The Federal, State and
Local Government should provide adequate drainage system along all the roads and ensure adequate maintenance of these systems.

\section{References}

1. Costa F.M. and Bacellar L., "Analysis of the Influence of Gully Erosion in the Flow Pattern of Catchment Streams," South Eastern Brazil. Catena, vol. 69, pp. 230-238, 2007.

2. - Peacock D.H. and Hoskin P.J., "Gully Erosion and Sediment Production," New Zealand Journal of Water resources, vol. 39 (7), pp. 1187, 2003.

3. De-Rouw A. and Girandin C., "Monitoring Soil Organic Carbon Erosion with Isotopic Tracers Two Case Studies on Cultivated Tropical Catchments with Steep Slopes," USA, Florida, Bocaraton: CRC press, 2005.

4. Jimoh, H.I., "Effects of Run-off on Sediment Transportation and Deposition in Ilorin City," Ajewole, OP: Emman, 2006.

5. Jimoh, H.I., "Erosion Tolerance Range of Land use and Management Techniques in Ilorin, Nigeria," Intern. Journal of Environ studies, vol. 60, 2003.

6. Poesen J., "Gully Topology and Gully Control Measures in the European Loss Belt," Amsterdam: Bugt Institute, 2003. 